\title{
An ichnofossil assemblage from the fluvial deposits of the Upper Pliocene-Pleistocene Pinjor Formation (Siwalik Group), northwestern Himalayas, India: Palaeoenvironmental implications
}

\author{
Ashu Khosla ${ }^{1}$ and Spencer G Lucas ${ }^{2}$,* \\ ${ }^{1}$ Centre of Advanced Study in Geology, Panjab University, Sector-14, Chandigarh 160014, India. \\ ${ }^{2}$ New Mexico Museum of Natural History, 1801 Mountain Rd. NW, Albuquerque, NM 87104, USA. \\ *Corresponding author.e-mail: spencer.lucas@state.nm.us
}

MS received 14 July 2017; revised 25 October 2017; accepted 10 November 2017; published online 30 June 2018

Continental (fluvial) strata of the Pinjor Formation (Siwalik Group), northwestern Himalayas, India, contain an invertebrate trace fossil assemblage containing Planolites beverleyensis, Palaeophycus isp., Scoyenia gracilis, Taenidium barretti and other undifferentiated traces. The traces are found in an $\sim 26 \mathrm{~m}$ thick interval of alternating pinkish red siltstone, which is intercalated with mudstone, and thickly-bedded buff and greenish coloured sandstone. These sediments are interpreted as the deposits of floodplains and channel-bars of fluvial environments and low-energy overbank floodplain deposits. The trace fossils studied here are the first well documented ichnofossil assemblage from the vast, late Cenozoic Siwalik depositional system. They are not only of palaeoenvironmental significance, but they add to the growing ichnofossil database in facies of fluvial origin and should be an impetus to further ichnological studies of the Siwalik Group.

Keywords. Upper Pliocene-Pleistocene; Pinjor Formation; palaeoenvironmental significance; Siwalik Group; Scoyenia ichnofacies.

\section{Introduction}

Continental ichnology has been developed extensively during the last two decades, so that there is now a greater understanding of organism-substrate interactions in non-marine deposits and the identification of several non-marine ichnofacies (Seilacher 1967; Frey et al. 1984; Maples and Archer 1989; Gierlowski-Kordesch 1991; Bromley and Asgaard 1991; Pickerill 1992; Buatois and Mángano 1993, 1995, 2002, 2007, 2011; Genise and Bown 1994; Buatois et al. 1998; Genise et al. 2000; Mángano et al. 2001, 2002; Mikuláš et al. 2004; Kim et al.
2005; Fernandes and Carvalho 2006; Melchor et al. 2006; Hunt and Lucas 2007; Ekdale et al. 2007; Gibert and Saez 2009; Krapovickas et al. 2009; Wang et al. 2014; Lucas 2016; Neto de Carvalho and Baucon 2016, etc.). Continental trace fossil distribution is controlled by many factors, including the level of the water table, soil moisture and ecological associations (Hasiotis 2007), and is distinct from marine trace fossil distribution (Smith 1993; Smith and Mason 1998; Hasiotis 2008; Hembree and Hasiotis 2008).

Continental ichnofaunas represent diverse traceproducing and have been studied throughout most 
of the Phanerozoic (Buatois and Mángano 1993, Buatois et al. 1998, 2007). Through the passage of geological time, trace-producing activities migrated from fluvial to lacustrine palaeoenvironments (Buatois et al. 1998). This reflects the colonization of nonmarine substrates by traceproducing organisms that faced various chemical and physical parameters that control organismsubstrate interactions in a terrestrial setting. These chemical factors encompass the chemistry of the substrate, including its oxygen content and the content of consumable organic matter, necessary for the respiration and sustenance of many tracemaking organisms. Physical parameters include substrate type, cohesion and rate of deposition: all factors that affect how well and how rapidly the substrate can be colonized.

To date the majority of ichnological studies in continental settings have been concentrated on freshwater paleosol (Genise et al. 2000) and lacustrine deposits (Buatois and Mángano 1993), whereas fluvial trace fossils have received less attention. The majority of trace fossils recorded from the present Nadah locality come from floodplain deposits, which typically host the profuse trace fossil assemblages in fluvial depositional environments (Buatois et al. 1997; Buatois and Mángano 2002).

In the northwestern Himalayas, continental ichnofossil assemblages of Plio-Pleistocene age are abundant in the Siwalik Group, but have been little described or reported (see Agarwal and Singh 1983; Tandon and Naug 1984; Chakraborty et al. 2013). Traces from the Siwalik Group are generally described as dwelling burrows (Agarwal and Singh 1983) and irregular excavations, burrows and tunnels (Tandon and Naug 1984). More recently, Chakraborty et al. (2013) recorded Planolites, Macanopsis, Naktodemasis, and Cylindricum from the middle Siwalik Group of the Darjeeling area (northeastern region). The ichnofossil assemblage of the Darjeeling area is quite different from the present Nadah locality, although the tracemakers from both localities suggest a channel-floodplain environment. Furthermore, previous descriptions of trace fossils from the Siwalik Group have tended to mix ichnotaxonomic descriptions with an evaluation of ethology and trophic behaviors (Agarwal and Singh 1983; Tandon and Naug 1984), whereas in this paper, we keep a clear separation between these aspects of the ichnofossil assemblages.

The present communication represents the first detailed description of the ichnofossils from the
Nadah locality in the Pinjor Formation of the Pliocene-Pleistocene Siwalik Group of the northwestern Himalayas, with respect to palaeoenvironmetal interpretations (figure 1A-B). Trace fossils in the Pinjor Formation at the Nadah locality were first noted by Tandon and Naug (1984) while describing the facies-trace fossil relationships. They mentioned that traces in the Pinjor Formation are of low diversity and representative of simple, unspecialized behaviours categorized under five ichnofacies and six bioturbated textures belonging to overbank, levees, and paleosol deposits.

Although a wealth of literature exists on the vertebrate faunas, ostracods, charophytes, plant megafossils, and palynofossils from the Upper Siwaliks (Pinjor Formation), trace fossils received little attention since they were preliminarily reported more than three decades ago by Tandon and Naug (1984). Tandon and Naug (1984) could not identify the trace fossils because of the scarcity of the known ichnological data at that time. The present authors did extensive field work at the Nadah section and collected numerous ichnofossils. In this study, we focus on fluvial deposits, which contain some of the most varied and plentiful trace-fossil assemblages recorded in non-marine depositional systems (Fordyce 1980; D'Alessandro et al. 1987; Nadon 1993; Buatois et al. 1997, 2007; Buatois and Mángano 2002, 2004, 2007; Kim et al. 2002; Zhang et al. 2004; Melchor et al. 2006; Krapovickas et al. 2009; Abdelkbir et al. 2012; Wang et al. 2016). Thus, the purpose of this paper is to systematically classify these unidentified materials by providing additional ichnological data from these much neglected freshwater trace fossils and to provide an up-to-date ichnotaxonomy.

The Nadah locality has been confirmed to be extremely rich in trace fossils and warrant a detailed description in a broader stratigraphic context. In this contribution, the trace fossil-bearing Nadah section from the Pinjor Formation near Panchkula, Haryana (figure 1A-B) is described. The present study is not projected as a complete description of the ichnology of the Pinjor Formation at Nadah, but it can be considered as a proxy of their trace fossil assemblages. Nevertheless, their more comprehensive study is essential for a better recognition of palaeoenvironment of these palaeontologically imperative deposits. Apart from trace fossils, the Nadah locality is highly fossiliferous, and fossils of various groups have 

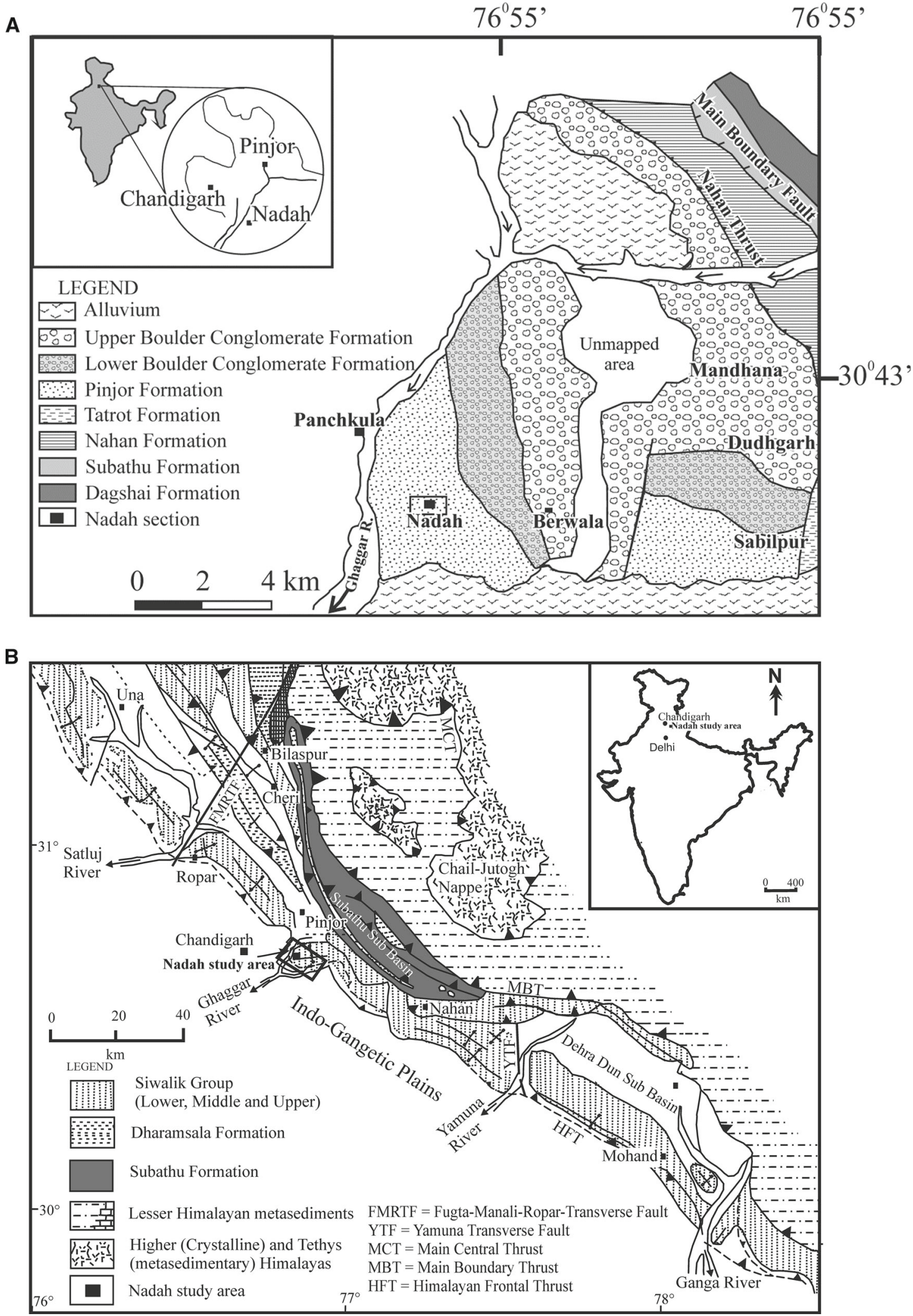

Figure 1. (A) Geological map of the trace fossil-bearing Nadah locality in the north-western Sub-Himalayan Zone, and distribution of Siwalik Group rocks in and around the studied section (modified after Kumar and Tandon (1985); Kumaravel et al. (2005)). (B) Geological map of the Himalayan sub-basin showing different lithostratigraphic and stratigraphic units. Location of the studied section (Nadah area) is also shown (modified and data compiled after Karunakaran and Ranga Rao 1976; Raiverman et al. 1983; Powers et al. 1998; Kumaravel et al. 2005). 
been reported, including rodents (Patnaik 2003), ostracods (Bhatia 1996), charophytes (Bhatia 1996, 1999), gastropods and palynomorphs (Patnaik 2003).

\section{Geological setting and lithostratigraphy of the studied section}

The Siwalik Group (18-0.7 Ma) in the foothills of the Himalayas forms part of the Sub-Himalayan Zone and lies between the Lesser Himalayan Zone and the active Himalayan Frontal Thrust (HFT, figure 1B). The Siwalik Group represents a fluvial sedimentary sequence deposited in a foreland basin of the Himalayan orogenic system (Pilgrim 1910, 1913; Tandon 1991). It consists of an $\sim 6000 \mathrm{~m}$ thick fluvial succession (Pilgrim 1910, 1913; Tandon 1991; Kumaravel et al. 2005), makes a more or less continuous belt in the Himalayan foothills and is famous for its vertebrate fossils (Tandon 1991; Patnaik 2003). Based on vertebrate faunal assemblages and lithofacies variation, these deposits have been classified into the lower, middle and upper subgroups (Pilgrim 1910, 1913; Tandon 1991; Kumaravel et al. 2005). Johnson et al. (1982) subdivided the Siwalik Group in Pakistan into a series of seven successive formation-rank units (in ascending order): Kamlial, Chinji, Nagri, Dhok Pathan, Tatrot, Pinjor and Boulder Conglomerate. The Pinjor Formation and Boulder Conglomerate, both categorized under the upper Siwalik Subgroup, are well exposed in the Indian subcontinent (Tandon 1991). Various workers have contributed to the general stratigraphy of the Siwalik Group, both in India and in Pakistan (Falconer 1868; Pilgrim 1910, 1913; Colbert 1935; Opdyke et al. 1979; Azzaorli and Napoleone 1982; Johnson et al. 1982).

The trace fossil-bearing section is exposed along the Ghaggar River in a westerly direction along the road leading to the village Nadah (figure 1A-B). In the east to Chandigarh, near the Nadah locality, the Pinjor Formation (2.6-1.79 Ma) yields abundant trace fossils. These trace fossil-bearing strata are of early Pleistocene age (1.8 Ma) and have been dated biostratigraphically and by palaeomagnetic and fission-track methods (Tandon and Kumar 1984; Azzaroli and Napoleone 1982; Ranga Rao et al. 1995; Patnaik 2003). The biochronostratigraphy of the Pinjor Formation along the Nadah area has been established out by Tandon (1991), Patnaik (2003), Kumaravel et al. (2005) and Chaudhari and Singh (2012). Kumaravel et al. (2005) and, more recently, Chaudhary and Singh (2012) proposed a stratigraphic classification for the Nadah section (Upper Siwalik) based on heavy mineral analysis, lithology and palaeontology. Kumaravel et al. (2005) divided the upper Siwalik Group into three formations: (1) Tatrot Formation (>60 $\mathrm{m}$ thick) of latest Pliocene age $(\sim 2.6 \mathrm{Ma})$, lithologically composed of fine- to coarse-grained, grey sandstones, variegated mudstones and siltstones; (2) Pinjor Formation (>380 m thick) of Plio-Pleistocene age $(\sim 2.6$ to $\sim 1.79 \mathrm{Ma})$ and lithologically composed of brown to greyish-brown, fine-, medium- and coarse-grained sandstones (0.5$4 \mathrm{~m})$, multi-storied sandstones $(\sim 9 \mathrm{~m})$, pebbly sandstones, pedogenic and non-pedogenic overbank facies $(2-15 \mathrm{~m})$; (3) Boulder Conglomerate Formation, which has been divided into members - Lower Boulder Conglomerate, which is $245 \mathrm{~m}$ thick and is of Pleistocene age $(\sim 1.79$ to $\sim 1.2 \mathrm{Ma})$, and lithologically consists of sandstones, mudstones and conglomerates, whereas the upper Boulder Conglomerate is $330 \mathrm{~m}$ thick and is also of Pleistocene age $(\sim 1.2$ to $\sim 0.5 \mathrm{Ma})$, and has thickly bedded conglomerates with pebbles, cobbles and boulders, sandstones and mudstones.

The Pinjor Formation has been interpreted to be deposited by rivers of a high gradient piedmont system. We measured a $57.5 \mathrm{~m}$ thick section of the Pinjor Formation near the Nadah locality. The trace fossil-bearing pinkish red siltstone is intercalated with mudstone and occasionally contains sandstone lenses and attains a thickness of about 5-27 $\mathrm{m}$ (figure 2). This unit is underlain by either buff/reddish sandstone $(2.5 \mathrm{~m})$ or overlain by very coarse grained greenish/buff sandstone $(6.0 \mathrm{~m})$. Identified traces from this pinkish red siltstone unit include Palaeophycus isp., Planolites beverleyensis, Scoyenia gracilis and Taenidium barretti.

\section{Material and methods}

About 20 slabs of pinkish red siltstone intercalated with mudstone were collected from the Upper Siwalik Group of Nadah village near Panchkula (Haryana) for this study. The slabs were broken and were directly collected from the aforementioned siltstone and mudstone rocks at Nadah. Four types of trace fossils are described in this paper based on architectural and surficial morphologies (Häntzschel 1975; Hasiotis 2004). The specimens described here are kept in repository 


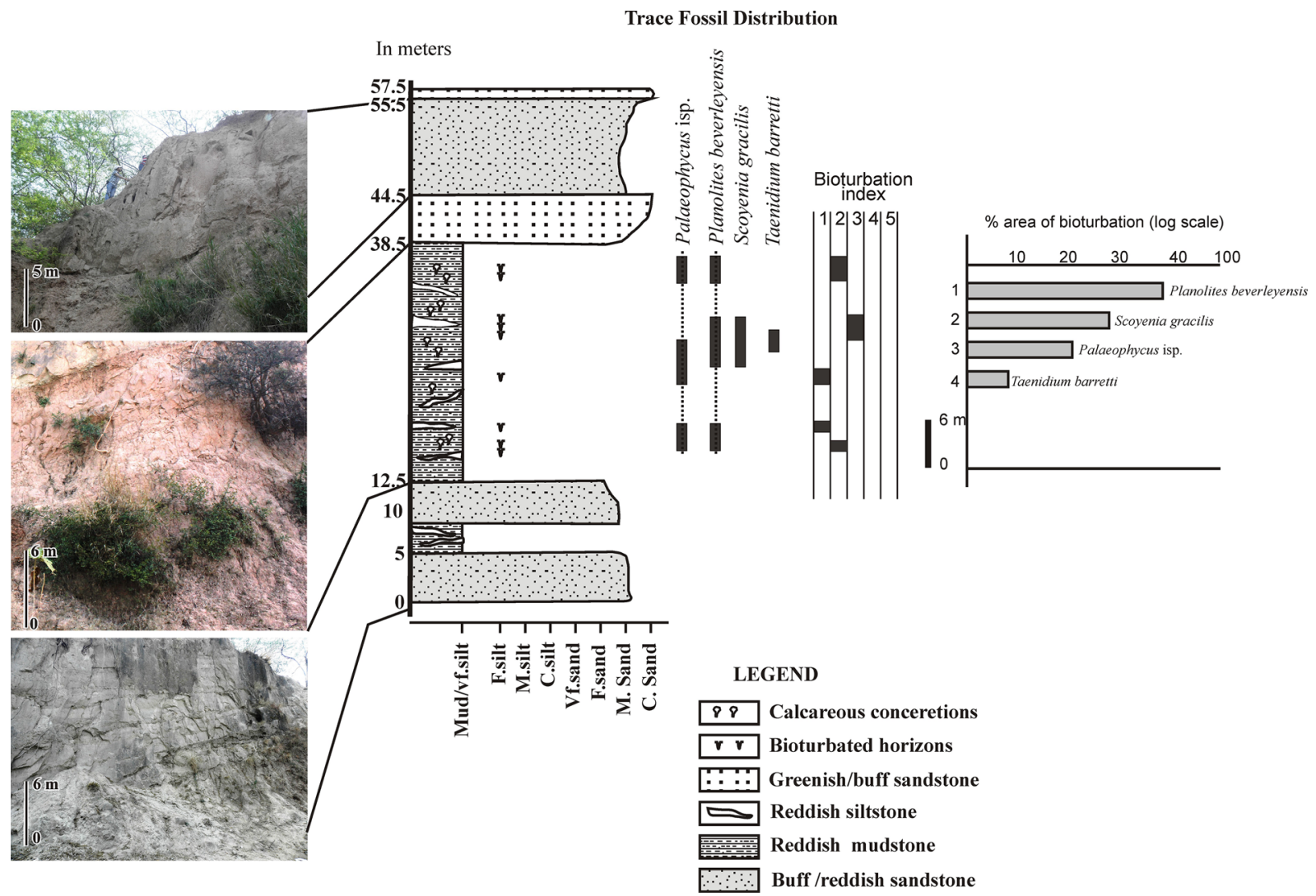

Figure 2. Detailed lithologic column of the trace fossil-bearing horizon showing the degree of bioturbation index at the Nadah locality, northwest Himalayas.

at the Centre of Advanced Study, Department of Geology, Panjab University, Chandigarh, with repository numbers assigned as VPL/AKH/PU/ ND/SW/01 to VPL/KH/PU/ND/SW/17. Abbreviations are No: Number; VPL/AKH/PU/ND/ SW; Vertebrate Palaeontology Laboratory, Ashu Khosla, Panjab University, Nadah, Siwaliks. The dimensions are given in millimetres $(\mathrm{mm})$. The samples, lithofacies, and trace-fossil assemblage of the Nadah area are shown in table 1.

\section{Result: Description of the trace fossils}

\subsection{Ichnogenus Palaeophycus Hall, 1847}

Palaeophycus isp. (figures 3A, B, 4C, 6D)

Material and horizon: Four slabs (VPL/ $\mathrm{AKH} / \mathrm{PU} / \mathrm{ND} / \mathrm{SW} / 01-03,13)$ with 20 specimens preserved in pinkish red siltstone.

Description: This trace fossil is a hypichnial, straight to curved and cylindrical burrow. Burrow diameters or cross sections are cylindrical to elliptical and range from 4 to $7 \mathrm{~mm}$. The orientation of the burrows to the bedding plane ranges from horizontal to oblique. The specimens are preserved in convex hyporelief. Burrow courses are straight to curved, with a maximum observed length of up to 30-80 mm long. There is no evidence of burrow collapse. Frequent crosscutting and interpenetration are seen between specimens. Systematic branching is not present. The burrow walls (sensu Bromley 1996) exhibit essentially parallel, longitudinal striations. Linings composed of sediment different in colour and texture from the burrow fill are very thin where present. The burrow fill is identical to the surrounding matrix.

Remarks: Palaeophycus has had a complex and confusing taxonomic history. A systematic review by Pemberton and Frey (1982) recognized five valid ichnospecies. They distinguished Palaeophycus from Planolites by the presence of wall linings and by Palaeophycus having a burrow fill identical to the surrounding matrix. Palaeophycus isp. is recognized from the Nadah locality as a thinly lined burrow. However, some specimens are sculpted by fine, continuous, parallel, longitudinal striae. Specimens from the Nadah locality are 


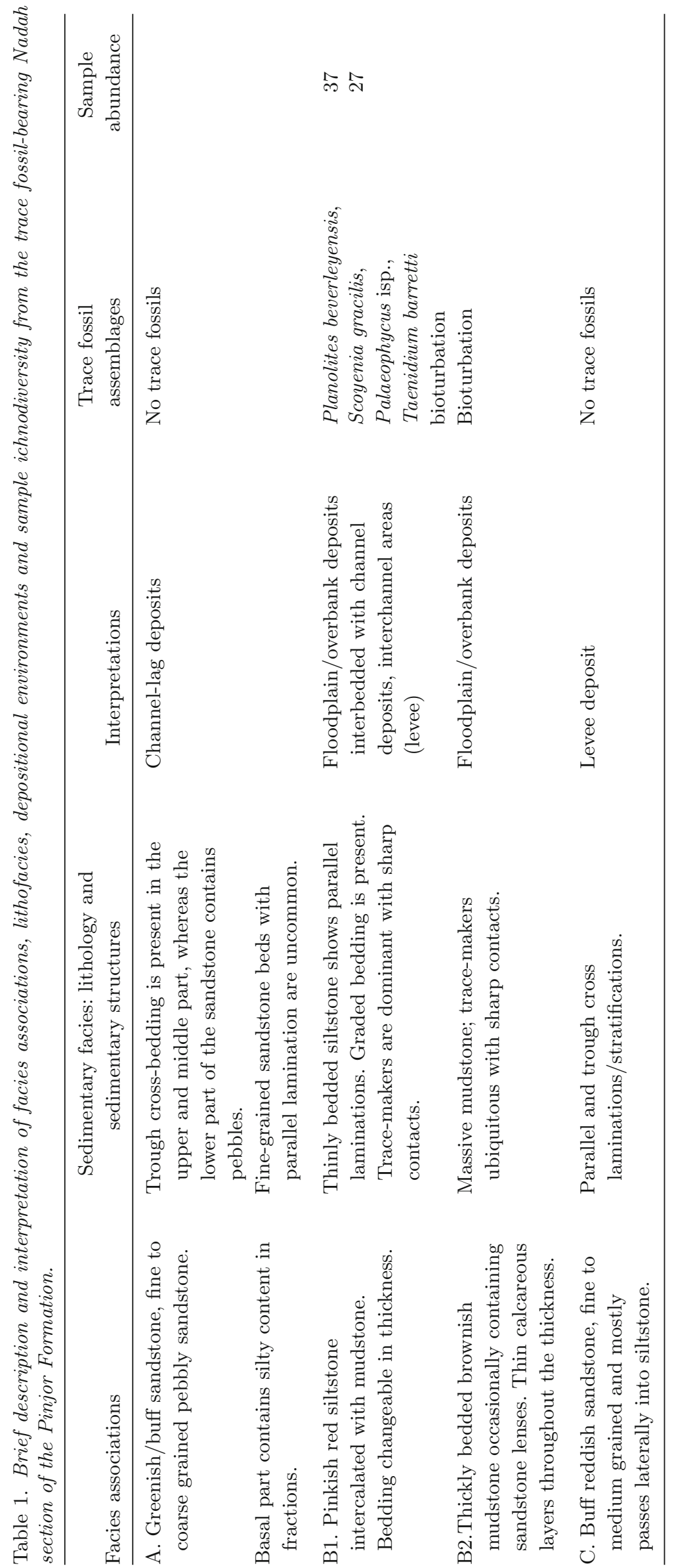



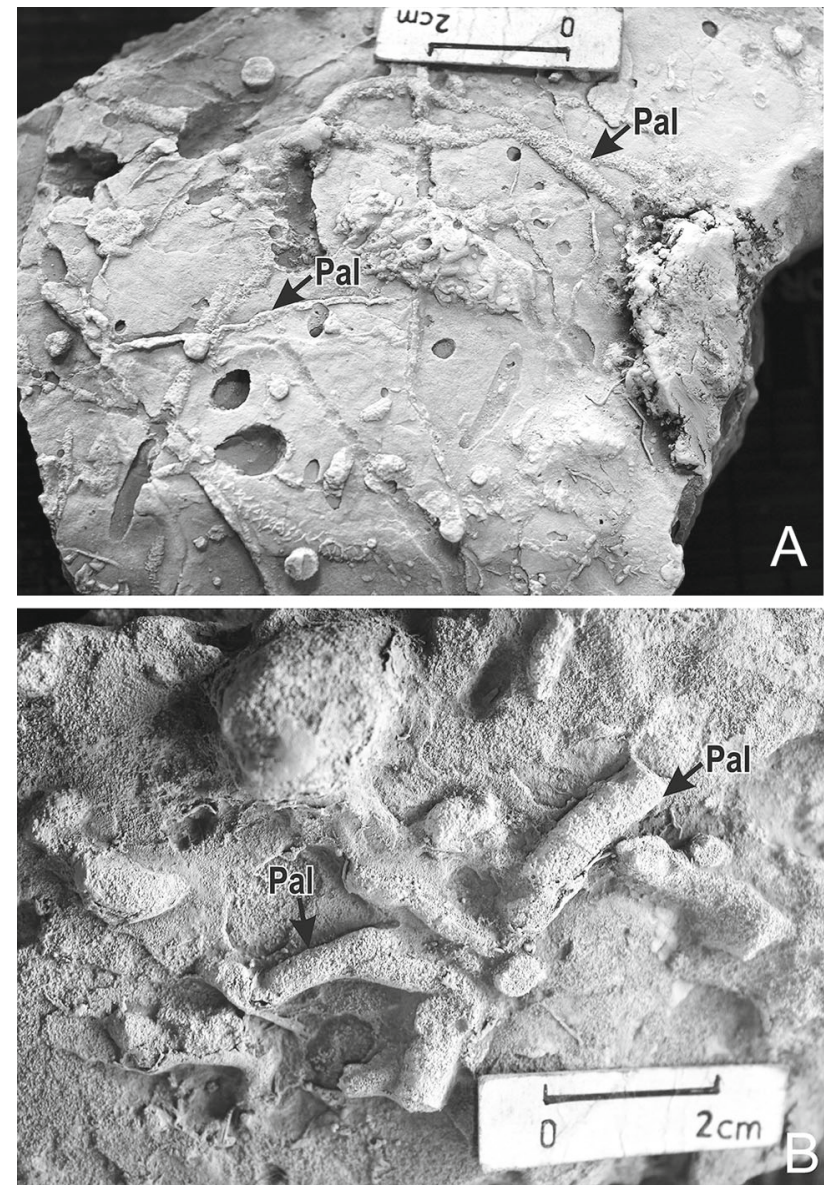

Figure 3. (A) and (B) Palaeophycus isp. (Pal), preserved in pinkish red siltstone slab (VPL/AKH/PU/ND/SW/01, 02), Pinjor Formation (upper Pliocene-Pleistocene), Nadah locality, northwestern Himalayas. Scale $=2 \mathrm{~cm}$.

conservatively assigned to Palaeophycus isp., though a few specimens may belong to P. striatus.

Palaeophycus isp. represents passive sedimentation within open dwelling burrows (domichnia) constructed by a predaceous or suspension feeding animal (Pemberton and Frey 1982). Osgood (1970) posited predaceous polychaetes as a modern analog of the tracemaker of Palaeophycus in marine environments. In fluvial environments, arthropods and other insects are the main tracemakers of Palaeophycus (Buatois and Mángano 1993). The burrow wall sculpture of $P$. striatus is considered to be the result of interior scraping or digging by the bristles or setae of the vermiform trace maker (Pemberton and Frey 1982). Buatois and Mángano (1993, 2002), Mángano et al. (2002), Gradzinski and Uchman (1994), Scott et al. (2009) and Lima and Netto (2012) discussed this ichnogenus and reported that Palaeophycus has been recorded from non-marine, marginal marine, shallow-marine, and deep marine settings, as well as from tidal flats. The age of this
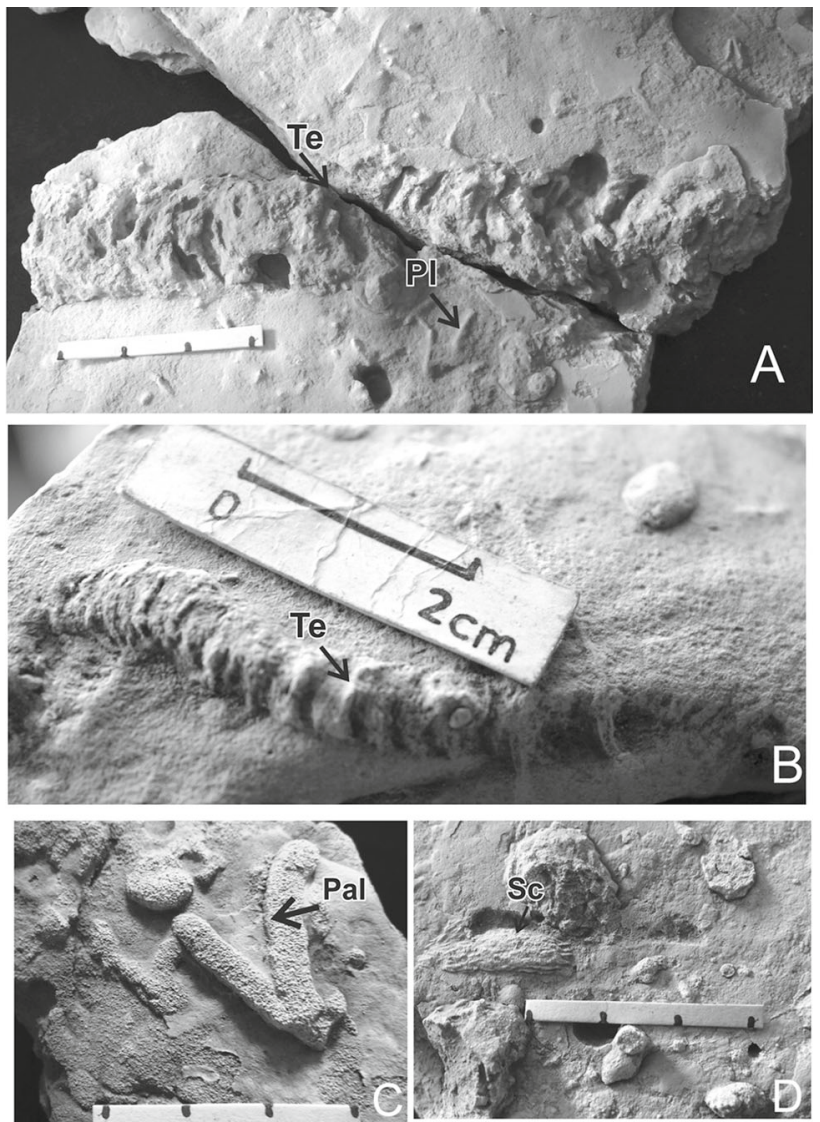

Figure 4. (A) Taenidium barretti (Te, VPL/AKH/PU/ND/ $\mathrm{SW} / 06)$, and Planolites beverleyensis (Pl, VPL/AKH/PU/ ND/SW/06), (B) Taenidium barretti (Te, VPL/AKH/ $\mathrm{PU} / \mathrm{ND} / \mathrm{SW} / 12$ ); (C) Palaeophycus isp. (Pal, VPL/AKH/ $\mathrm{PU} / \mathrm{ND} / \mathrm{SW} / 03$ ); (D) Scoyenia gracilis (Sc, VPL/AKH/ $\mathrm{PU} / \mathrm{ND} / \mathrm{SW} / 09)$ preserved in pinkish red siltstone, Pinjor Formation (upper Pliocene-Pleistocene), Nadah locality, northwestern Himalaya. Scale $=3 \mathrm{~cm}$ for figures A, C and D; scale $=2 \mathrm{~cm}$ for figure B.

ichnotaxon ranges from Proterozoic to Holocene (Pemberton and Frey 1982).

\subsection{Ichnogenus Planolites Nicholson, 1873}

Planolites beverleyensis Billings (1862) (figures 4A, $5 \mathrm{~A}, 6 \mathrm{D})$

Material and horizon: Four slabs (VPL/ $\mathrm{AKH} / \mathrm{PU} / \mathrm{ND} / \mathrm{SW} / 04-06,13)$ with 37 specimens preserved in pinkish red siltstone.

Description: The specimens are simple, smooth, cylindrical tubes with a circular to ellipsoidal cross-section. Tube diameters range from 1 to $2 \mathrm{~mm}$ with lengths highly variable because the traces are not parallel to bedding. Planolites burrows are preserved as hyporeliefs. In plan view, the burrows are straight to slightly sinuous 


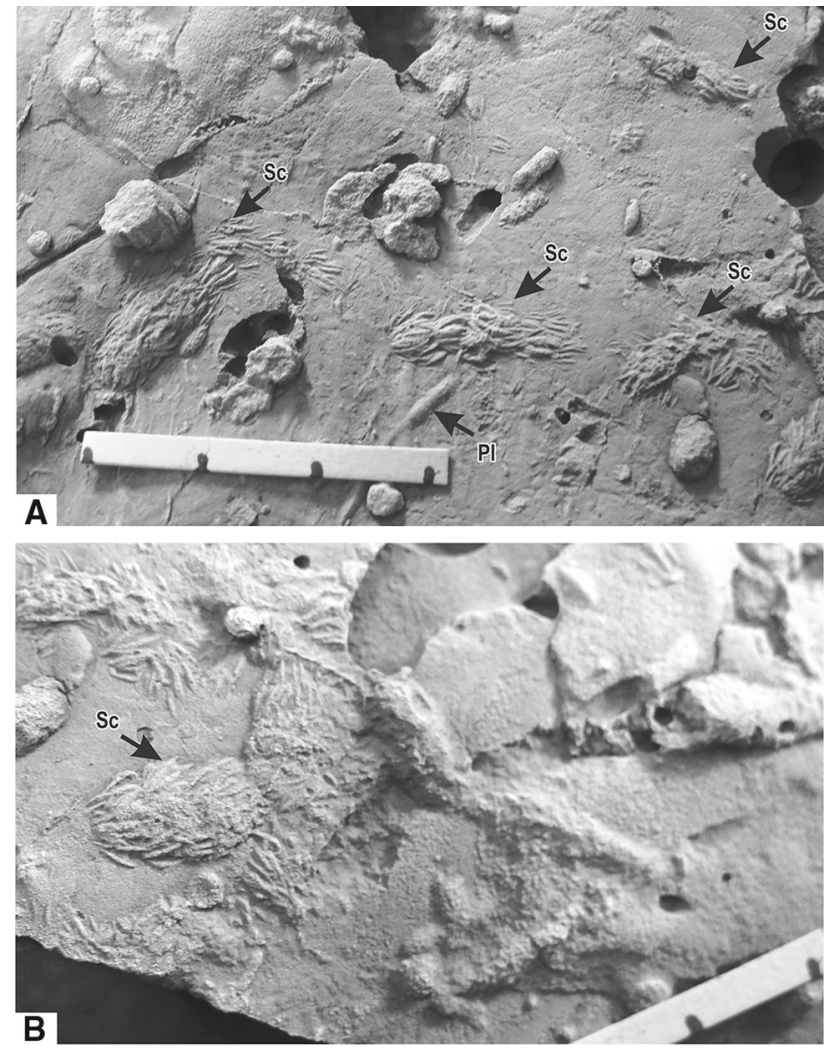

Figure 5. (A) Scoyenia gracilis (Sc) and Planolites beverleyensis (Pl, VPL/AKH/PU/ND/SW/05) (B) Scoyenia gracilis (Sc, VPL/AKH/PU/ND/SW/11) preserved in pinkish red siltstone slab, Pinjor Formation (upper PliocenePleistocene), Nadah locality, northwestern Himalayas. Scale $=3 \mathrm{~cm}$.

and may crosscut each other. The burrow fill differs texturally from the host rock sediments. The fill is mostly finer-grained than the surrounding material, though structure-less infill or infill coarser than the surrounding rock are also present. The burrow is straight to slightly sinuous and parallel or oblique to vertical with respect to bedding. The sinuous burrow frequently intersects the bedding plane over a short distance. Burrow overlap is rare.

Remarks: Palaeophycus and Planolites are two ichnogenera that have been frequently compared. Morphologically, Palaeophycus is passively filled and lined, whereas Planolites is actively filled and unlined (Pemberton and Frey 1982). P. beverleyensis is characterized by a simple, even, straight to somewhat curved burrow whose fill is dissimilar from the lithology of host rock sediments. According to Pemberton and Frey (1982), the presence of straight or somewhat curved burrows and having a diameter up to $8 \mathrm{~mm}$ are the main features of Planolites beverleyensis, whereas the lack of characteristic features such as grooves and annulations in the Nadah specimen preclude the option of including them in $P$. terranovae and P. annularius (Buatois and Mángano 1993). The present specimens from Nadah show the morphological characters of Planolites beverleyensis (Billings 1862), so they are grouped under this ichnospecies.

\subsection{Ichnogenus Scoyenia White, 1929}

Scoyenia gracilis White (1929) (figures 4D, 5A, B, $6 \mathrm{~A}, \mathrm{~B}, \mathrm{D})$

Material and horizon: Five slabs (VPL/ AKH/PU/ND/SW/05, 09, 11, 13, 14, 15) with 27 specimens preserved in pinkish red siltstone.

Description: The burrows are unbranched, unlined, straight to sinuous, vertical to horizontal, undulose, cylindrical tubular burrows, with distinct meniscate fill. The diameter of the burrow is variable. The external surfaces are marked by longitudinal or oblique, straight to slightly curving ridges and grooves.

Remarks: The rope-like external striations as well as the meniscate backfill are characteristic features of Scoyenia (Frey et al. 1984; Keighley and Pickerill 1994). The exterior scratch ornaments are also characteristics of Scoyenia. Taenidium and Beaconites are back-filled burrows similar to Scoyenia, but differ in lacking the striated, clayey wall lining of Scoyenia (Häntzschel 1975). Scoyenia is a common trace fossil in continental settings (e.g., Frey et al. 1984; Gibert and Saez 2009). Arthropods are favoured as possible producers, but insects and decapods are specific kinds of arthopods that cannot be excluded (Frey et al. 1984). Records of Scoyenia have been recorded from as far back as the early Palaeozoic (Retallack 2001).

\subsection{Ichnogenus Taenidium Heer, 1877}

Taenidium barretti Bradshaw (1981) (figures 4A, $\mathrm{B}, 6 \mathrm{C}, \mathrm{D})$

Material and horizon: Four slabs (VPL/ $\mathrm{AKH} / \mathrm{PU} / \mathrm{ND} / \mathrm{SW} / 05,06,13,16,17)$ with seven specimens preserved in pinkish red siltstone.

Description: The burrows are vertical to horizontal. They are highly sinuous, elongate, and endichnial burrows, which are $1-6 \mathrm{~mm}$ in diameter and up to $27 \mathrm{~mm}$ long. They are composed 

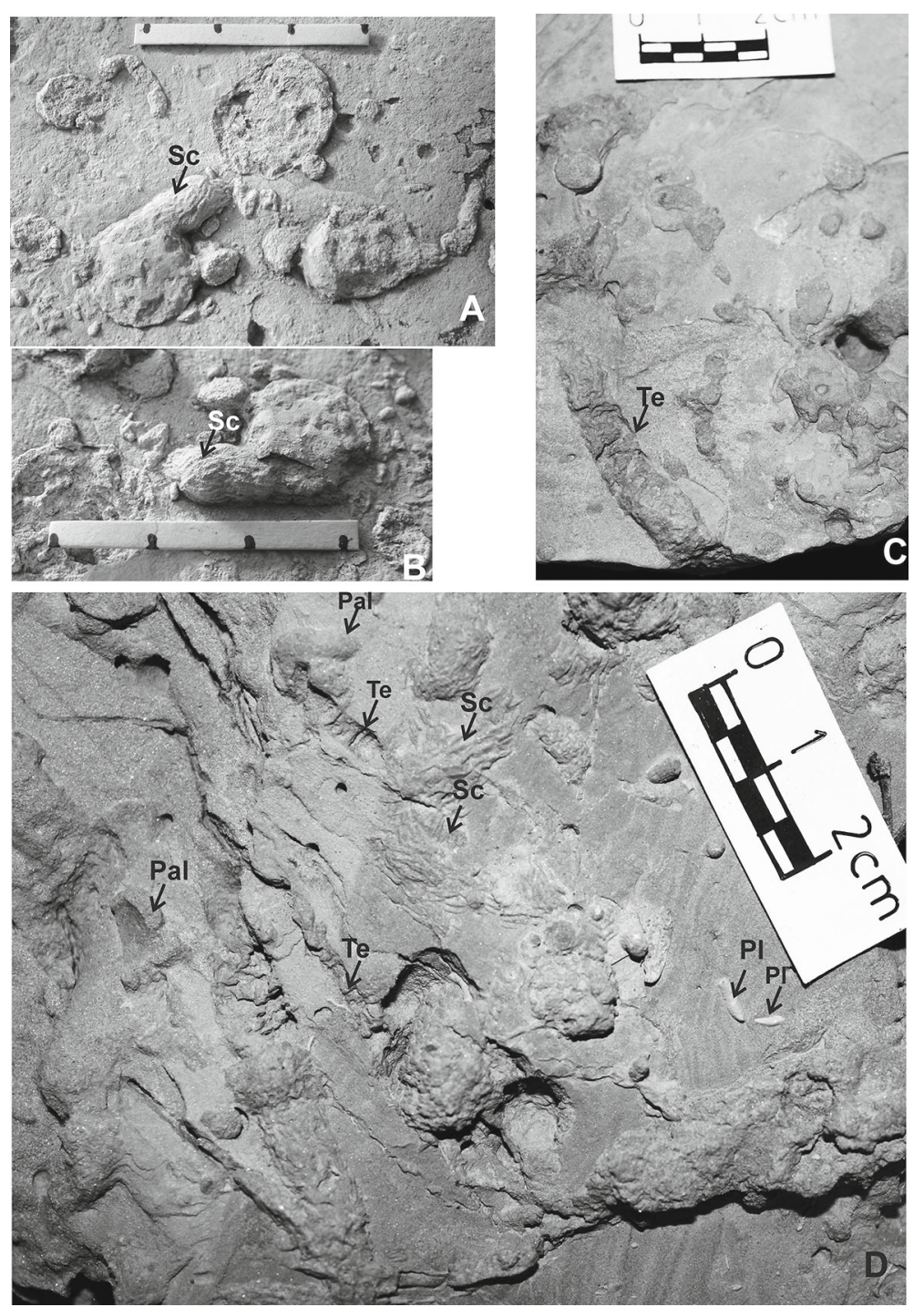

Figure 6. (A) and (B) Scoyenia gracilis (Sc, VPL/AKH/PU/ND/SW/ 14, 15), (C) Taenidium barretti (Te, VPL/AKH/PU/ND/SW/16, 17) and (D) Palaeophycus isp. (Pal), Planolites beverleyensis(Pl), Scoyenia gracilis (Sc) and Taenidium barretti (Te, VPL/AKH/PU/ND/SW/13) preserved in pinkish red siltstone slab, Pinjor Formation (upper Pliocene-Pleistocene), Nadah locality, northwestern Himalayas. Scale for figures A and B $=3 \mathrm{~cm}$; figures $\mathrm{C}$ and $\mathrm{D}=2 \mathrm{~cm}$.

of poorly organized packets of meniscus-shaped, structureless backfill, and sometimes organized packets are identical to the host sediment. There is no evident lining, and surficial morphology is smooth.

Remarks: The ichnotaxonomy of meniscate burrows, in particular, the distinction between Beaconites and Taenidium, is problematic (Keighley and Pickerill 1994; Goldring and Pollard 1995). Following Keighley and Pickerill (1994), the material from the Siwaliks lacks a constructed wall, shows closely spaced menisci, and has a mantle of relatively small diameter, which is characteristic of Taenidium barretti. T. barretti was initially erected by Bradshaw (1981) because of the presence of large, meniscate, backfilled burrows. Later, Taenidium was revised by Keighley and Pickerill (1994) and Uchman (1999). Morrissey and Braddy (2004) described small forms of Taenidium from Upper Devonian and Permian deposits of the United Kingdom. More recently, Gouramanis and Mcloughlin (2016) discovered large Taenidium up to $40 \mathrm{~cm}$ in diameter in Siluro-Devonian deposits. These burrows are unbranched, straight to slightly sinuous, essentially cylindrical in cross section, possess meniscate backfilling and are unlined, which justifies their assignment to Taenidium barretti (Bradshaw 1981; Pollard et al. 1982; Pollard and Walker 1984).

Various animals have been proposed as the producers of Taenidium, including polychaetes 
(Gevers et al. 1971), amphibians or reptiles (Ridgway 1974), and arthropods (Bradshaw 1981; Keighley and Pickerill 1997; Morrissey and Braddy 2004). The presence of menisci and lack of a burrow lining in $T$. barretti indicate that it was actively backfilled, with each meniscus representing a period of activity.

\section{Discussion}

\subsection{Ichnofacies approaches at Nadah and their global comparison}

The major trace fossils in this ichnoassemblage are the feeding traces Taenidium barretti, Planolites beverleyensis, Palaeophycus isp., and Scoyenia gracilis (table 1). It has been well documented that usually the trace fossils that are profuse and are of low diversity are in order along, or inclined at a high angle to, the bedding plane (Wang et al. 2016). The ichnofauna from Nadah area records an instance of the Scoyenia ichnofacies. The initial naming and work on the Scoyenia ichnofacies was by Seilacher (1963, 1967), and later, various workers, such as Frey et al. (1984) and Buatois and Mángano (1995), worked out the finer details of this ichnofacies. The archetypal ichnotaxa consist of meniscate trace fossils such as Taenidium and Scoyenia, whereas simpler traces are represented by Palaeophycus and Planolites. The Scoyenia ichnofacies is most often represented by low diversity meniscate trace fossils (Frey et al. 1984), as at Nadah, and a similar situation has also been recorded from the freshwater fluvial deposits of the Miocene of Bolivia (Buatois et al. 2007). The sedimentary structures recorded from the Scoyenia ichnofacies are usually suggestive of episodic subaerial exposure and further epitomize low-energy and intermittent conditions of deposition, so that the substrate has been episodically exposed to the atmosphere or at regular intervals, and the depositional environment is transitional between aquatic and nonaquatic environments (Frey and Pemberton 1984, 1987; Buatois et al. 2007).

Lithologically, this ichnoassemblage at Nadah is well developed in the thin bedded siltstones or silt-bearing mudstones and always associated with gentle laminations and graded bedding, which further reveal low energy conditions of aqueous deposition. This ichnofacies has been widely recorded from the freshwater fluvial system, especially in overbank and channel deposits that surrounded an extensive assortment of subenvironments (for example, crevasse splays, ponds and levees: Frey et al. 1984; Frey and Pemberton 1984, 1987; Buatois and Mángano 1995, 2002, 2004; Buatois et al. 2007).

During the last two decades, various workers, including Bromley (1996), Buatois et al. (1996), Savrda et al. (2000), Buatois and Mángano (2002, 2004), and Uchman et al. (2004), have emphasized the significance of substrate consolidation in the Scoyenia ichnofacies. In the Scoyenia ichnofacies, two distinct suites have been recognized. The first is identified by the presence of striated traces (Scoyenia gracilis) and developed in a firm substrate (Buatois and Mángano 2002), and the second by the lack of any kind ornamentation and by meniscate, backfilled structures (Taenidium) that colonized a soft substrate (Buatois et al. 2007). It has often been noticed that most of the trace fossils belonging to the Scoyenia ichnofacies reveal progressive desiccation of the sediment (Buatois et al. 2007).

In the present sample of meniscate-bearing Taenidium barretti from the Nadah area, striations have not been noticed, which suggests emplacement in a comparatively wet and soft substrate. The presence of pinkish-red coloured siltstone/mudstone points to extensive desiccation under semi arid conditions. Apart from the presence of Taenidium and Scoyenia, the Nadah ichnoassemblage also contains Planolites beverleyensis and Palaeophycus isp., which are of low diversity and also are present in the fine-grained, pinkish-reddish siltstones and mudstones. This ichnoassemblage, unlike previous ones reported nearby, includes the presence of calcareous concretions and desiccation cracks, which further reveal a semi-arid climatic environment. Tandon and Naug (1984) recorded the presence of rhizoliths associated with this assemblage, which was unidentified at that time, and their occurrence reflects a floodplain environment and very shallow water conditions. At the Nadah locality, ichnoassemblages have been recorded in five horizons. Individually, the bioturbation index (Miller and Smail 1997) varies from 1 to 3 (figure 2). Overall ichnofabric constitutions for individual ichnotaxa are provided in figure 2.

Similar sedimentological conditions and ichnofossil palaeoenvironments in a fluvial system developed under semi-arid conditions have also been recorded from the Miocene fluvial deposits of the Tariquia Formation of Bolivia 
(MacNaughton and Pickerill 1995; Buatois et al. 2007). The ichnoasemblage of the Nadah area also shows distinct affinities and is very comparable to that from the Toro Negro Formation, Argentina and of Cenozoic age. The Argentina formation shows the presence of dwelling tubes and a large number of meniscate ichnofossils, such as Taenidium and Scoyenia (Krapovickas et al. 2009).

The four types of ichnoassemblages described from the Nadah area can now safely be classified under the Scoyenia ichnofacies, which is usually characterised (Buatois and Mángano 1993, 2002, 2004; Buatois et al. 2007; Wang et al. 2016) by (1) meniscate backfilled burrows (Scoyenia and Taenidium), (2) simple horizontal traces (Planolites and Palaeophycus), (3) the presence of calcareous concretions, (4) a mixture of invertebrate and plant traces, and (5) low ichnodiversity (confined to a small area) with high abundance.

Elsewhere in the world, ichnoassemblages and palaeoenvironments similar to Nadah area have also been recorded from various stratigraphic units, for instance: ephemeral lacustrine deposits of the upper Silurian and lower Devonian of the AngloWelsh Basin, United Kingdom (Morrissey et al. 2012); the Tupe Formation of Carboniferous age, representing desiccated floodplain deposits in western Argentina (Buatois and Mángano 2002); fluvial deposits of the Permian Ikakern Formation (Argana Basin, Western High Atlas, Morocco, Abdelkbir et al. 2012); fluvial floodplain deposits of the Middle Triassic Youfangzhuang Formation in western Henan, central China (Wang et al. 2014); the non-marine Upper Triassic of the Haßberge area (Franconia, southeastern Germany, Schlirf et al. 2001); fluvio-lacustrine deposits in the early Mesozoic of Argentina (Melchor et al. 2006); the nonmarine Cretaceous of the Hasandong and Jinju formations of the Namhae Area, Kyongsangnamdo, southeast Korea (Kim et al. 2002); the Upper Cretaceous fluvial and lacustrine deposits in the Sichuan Basin (Hu and Wu 1993) and Xixia Basin, Henan of China (Zhang et al. 2004); and Upper Cretaceous channel, levee and crevasse splay, floodplain, and fluvio-lacustrine deposits of the Gaogou, Majiachun and Sigou formations in the Xixia Basin of southwestern Henan province, China (Wang et al. 2016). In all of the above-mentioned localities, which belong to different geological ages, most of the ichnofauna is characterised by a low diversity of simple forms and shallow trace fossils that were formed as an amalgamation of grazing, dwelling and locomotion structures (Wang et al. 2016).

\subsection{Palaeoenvironmental implications}

Trace fossils of upper Pliocene-Pleistocene age are documented herein for the first time from the Pinjor Formation of the Siwalik Group of the northwestern Himalayas. Lithologically, the Nadah section comprises fine-to-medium and coarsegrained, reddish, buff and greenish coloured sandstones, and very fine-grained, pinkish red siltstone and mudstone. This unit, particularly the pinkish red siltstone intercalated with mudstone, yields an ichnofossil assemblage containing Taenidium barretti-Scoyenia gracilis bioturbation produced by the multiple feeding and resting behaviours of arthropods of unknown affinity in alluvial fan deposits (Neto de Carvalho and Baucon 2016). The overall depositional conditions at the Nadah locality indicate the occurrence of a large freshwater body, which had been developed in a floodplain environment where fine-grained mudstones later filled the channel. The calcareous mudstone represents overbank deposits, i.e., interchannel areas off of the levee (Tandon and Naug 1984). Trace fossils are abundantly preserved in pinkish red siltstone lithofacies, which represents levee and channelfloodplain palaeoenvironments (Tandon and Naug 1984). Based on different lithotypes, Kumaravel et al. (2005) interpreted the Pinjor Formation as deposits of high gradient streams of low sinuosity and chiefly of a piedmont drainage system. The bedding has been obliterated in the trace fossilbearing horizon, and carbonate palaeosols and calcareous concretions (calcrete) are ubiquitous in mudstones, which further points to a semi-arid climate (Patnaik 2003).

The floodplain and overbank deposits from the Nadah locality contain an abundant but low diversity assemblage of invertebrate trace fossils that seems to be associated with only one lithofacies, the pinkish red siltstone/mudstone. The trace fossils Palaeophycus and Scoyenia appear to be preserved in siltstone (floodplain environment) interbedded with channel deposits under semi-arid conditions. Planolites beverleyensis seem to have been formed in soft ground (subaqueous environment) due to the indistinguishable boundary between the host rock and the burrows. The morphological features of this ichnoassemblage are weakly preserved, further pointing towards its deposition in muddy bottoms in overbank deposits. Taenidium barretti has also been preserved in interbedded, pinkish redcoloured, silty mudstone. These burrows have not been surficially exposed for a long time at the time 
of formation, and this might explain the absence of vertebrate traces and resting traces. The presence of a few mudcracks in this lithounit further point towards a short-lived desiccation event. T. barretti, like Planolites beverleyensis, appears to have been formed in low energy floodplain/overbank deposits.

Apart from the ichnofossils, palaeoecological interpretations are based on microfossil assemblages. Palaeoecologically, the Nadah freshwater assemblage represents a large microvertebrate fauna, particularly of mammals (Bandicota sp., Crocidura sp., Cremnomys cf. C. blanfordi, Patnaik 1997, Dilatomys sp., Golunda sp., Mus cf. M. flynni Patnaik 1997, and cf. Tatera Patnaik 1997); a fish (Cyprinidae indet. Patnaik 1997); a frog (cf. Rana sp.), and a lizard (Uromastyx Patnaik 1997). The molluscan assemblages are represented by genera such as Gyraulus and Viviparus, whereas bivalves belong to the genus Pisidium (Patnaik 1997). The charophyte taxa are dominated by four species, for instance Lamprothamnium papulosum (Wallr.) Groves (1916), Sphaerochara prolifera (Zizermann ex. A. Braun) Soulié-Märsche (1989), Chara globularis aspera Deth. ex. Wild. Wood (1962) and Chara globularis globularis (Thuillier 1799 in Bhatia 1999). Furthermore, ostracod taxa such as Strandesia indica (Hartmann 1964), Hemicypris megalops (Sars 1903) and Ilyocypris bradyi (Sars 1890), carbonised wood, and pollen have already been reported from the Nadah locality (Patnaik 2003).

Based on the presence of diverse microfossils, communities such as pond, pond bank, bushland, grassland, temperate montane and sandy plain habitats have been reconstructed (Patnaik 2003) around the trace fossil-bearing Nadah locality. Palaeoenvironmentally, the presence of lizards together with gerbil rodents, for instance cf. Tatera, indicates the occurrence of alternating dry periods in semi-arid climatic conditions (Patnaik 2003). Wet and dry periods together with lowland, freshwater swampy environmental conditions have been confirmed by the presence of a diverse palynological assemblage (Bhatia 1996; Patnaik 2003).

\section{Conclusions}

Low diversity trace fossils of the Scoyenia ichnofacies have been recorded in abundance from two broad and different depositional settings (fluvial deposits) of the Pliocene-Pleistocene Siwalik Group (northwestern Himalayas). Most of the trace fossils are preserved in fine-grained pinkish red siltstone intercalated with mudstone formed under semi-arid conditions. The trace fossil assemblages from the Pinjor Formation are archetypal representatives of the Scoyenia ichnofacies. The ichnoassemblage of Palaeophycus isp., Planolites beverleyensis and Taenidium barretti is typical of intermittently subaerial channel margins and floodplain depositional settings. These were low energy settings of channel margins and the floodplain overbank that were colonized by a low diversity of shallow burrowing and grazing arthropods in what must have been relatively unstable substrates. This instability explains why the Nadah ichnoassemblage is of such low diversity, as both palaeoenvironmental and taphonomic factors precluded colonization and/or preservation of the traces of a more diverse community of tracemakers.

\section{Acknowledgements}

One of us (AK) thanks the financial support for the research grants provided by the Department of Science and Technology (DST Purse Project, Panjab University, Chandigarh) and New Delhi (grant no. SR/S4/ES-382/2008). We are indebted to Dr B P Singh (Chandigarh, India) for helping us in many ways. We would like to express our gratitude to the three anonymous reviewers for their critical and helpful comments, which have considerably improved the manuscript. Special thanks also to the Associate Editor, whose comments were of great value in preparing the final version of the manuscript.

\section{References}

Abdelkbir H, Voigt, S, Hafid S, Jörg W S and Driss H 2012 On a moderately diverse continental ichnofauna from the Permian Ikakern Formation (Argana Basin, Western High Atlas, Morocco); J. Afr. Ear. Sci. 68 15-23.

Agarwal S C and Singh I B 1983 Palaeoenvironment and trace fossils of the Middle Siwalik sediments, Haridwar, Uttar Pradesh; J. Palaeontol. Soc. India 28 50-55.

Azzaorli A and Napoleone G 1982 Magnetostratigraphic investigations of the Upper Siwaliks near Pinjor, India; Riv. Ital. Paleontol. Strat. 87 739-762.

Bhatia S B 1996 The Ostracoda fauna and the Charophyte flora of the Siwalik Group: Palaeogeographic and palaeoecologic implications; Pub. Cent. Adv. Stu. Geol. Panj. Univ. 5 99-106.

Bhatia S B 1999 Revision of the Charophyte flora of the Siwalik Group (Neogene-Quaternary) of the Lesser Himalaya, India; Austr. J. Bot. 47 49-474. 
Billings E 1862 New species of fossils from different parts of the Lower, Middle and Upper Silurian rocks of Canada; In: Palaeozoic Fossils, Volume I (1861-1865) Geol. Surv. Canada and Dawson Broth. 1 96-168, Montreal.

Bradshaw M A 1981 Palaeoenvironmental interpretations and systematics of Devonian trace fossils from the Taylor Group (Lower Beacon Supergroup), Antarctica; New Zealand J. Geol. Geophys. 24 615-652.

Bromley R G 1996 Trace Fossils; Biology, Taphonomy and Applications; London, Chapman and Hall, 361p.

Bromley R G and Asgaard U 1991 Ichnofacies: A mixture of taphofacies and biofacies; Lethaia 24 153-163.

Buatois L A and Mángano M G 1993 Trace fossils from a Carboniferous turbiditic lake: Implications for the recognition of additional nonmarine ichnofacies; Ichnos 2 237-258.

Buatois L A and Mángano M G 1995 The paleoenvironmental and paleoecological significance of the lacustrine Mermia ichnofacies: An archetypical subaqueous nonmarine trace fossil assemblage; Ichnos 4 151-161.

Buatois L A and Mángano M G 2002 Trace fossils from Carboniferous floodplain deposits in western Argentina: Implications for ichnofacies models of continental environments; Palaeogeogr. Palaeoclimatol. Palaeoecol. 183 71-86.

Buatois L A and Mángano M G 2004 Animal-substrate interactions in freshwater environments: Applications of ichnology in facies and sequence stratigraphic analysis of fluviolacustrine successions; In: The Application of Ichnology to Palaeoenvironmental and Stratigraphic Analysis (ed.) McIlroy D, Geol. Soc. Spec. Publ. London 228 311-335.

Buatois L A and Mángano M G 2007 Invertebrate ichnology of continental freshwater environments; In: Trace fossils, Concepts, problems and prospects (ed.) Miller W III, Elsevier, Amsterdam, pp. 285-323.

Buatois L A, Jalfin G and Acenolaza F G 1997 Permian nonmarine invertebrate trace fossils from southern Patagonia, Argentina: Ichnologic signatures of substrate consolidation and colonization sequences; J. Palaeontol. 71 324-336.

Buatois L A and Mángano M G 2011 Ichnology: Organism substrate interaction in space and time; Cambridge University Press, Cambridge, 358p.

Buatois L A, Mángano M G and Aceñolaza F G 1996 Icnofaunas paleozoicas en sustratos firmes no marinos: Evidencias del Pérmico de la cuenca Paganzo; Ameghiniana 33 265-270.

Buatois L A, Mángano M G, Maples C G and Lanier W P 1998 Ichnology of an Upper Carboniferous fluvioestuarine paleovalley: the Tonganoxie Sandstone, Buildex Quarry, eastern Kansas, USA; J. Paleontol. 72 152-180.

Buatois L A, Uba C, Mángano M G, Hulka C and Huebeck C 2007 Deep and intense bioturbation in continental environments: evidence from Miocene fluvial deposits of Bolivia: In: Sediment-Organism Interactions: A Multifaceted Ichnology (eds) Bromley R G, Buatois L A, Mángano M G and Genise J F; SEPM (Soc. Sedim. Geol.) 88 123-136.

Chakraborty A, Hasiotis S T, Ghosh B and Bhattacharya H N 2013 Fluvial trace fossils in the Middle Siwalik (Sarmatian-Pontian) of Darjeeling Himalayas, India; $J$. Earth Syst. Sci. 122(4) 1023-1033.
Chaudhari A R and Singh M 2012 Clay minerals as climate change indicators: A case study; Am. J. Clim. Chan. 1 231-239.

Colbert E H 1935 Siwalik mammals in the American Museum of Natural History; Trans. Am. Phil. Soc. New Ser. 26 $1-401$.

D'Alessandro A, Ekdale A A and Dane Picard M 1987 Trace fossils in fluvial deposits of the Duchesne River Formation (Eocene), Uinta Basin, Utah; Palaeogeogr. Palaeoclimatol. Palaeoecol. 61 285-301.

Ekdale A, Bromley R and Loope D 2007 Ichnofacies of an ancient erg: A climatically influenced trace fossil association in the Jurassic Navajo Sandstone, southern Utah, USA; In: Trace fossils: Concepts, problems, prospects (ed.) Miller W C, Elsevier, Amsterdam, pp. 562-574.

Falconer H 1868 Introductory observations on the geography, geological structure and fossil remains in the Siwalik hills; Palaeontol. Mem. 1 1-29.

Fernandes A C S and Carvalho I D S 2006 Invertebrate ichnofossils from the Adamantina Formation (Bauru basin, Late Cretaceous), Brazil; Rev. Bras. Paleontol. 9(2) 211-220.

Fordyce R W 1980 Trace fossils from Ohika Formation (Pororari Group, Lower Cretaceous), lower Buller Gorge, Buller, New Zealand; J. Geol. Geophys. 23 121-124.

Frey R W and Pemberton S G 1984 Trace fossils facies models; In: Facies models (ed.) Walker B G, Geoscience Canada, pp. 189-207.

Frey R W, Pemberton S G and Fagerstrom J A 1984 Morphological, ethological, and environmental significance of the ichnogenera Scoyenia and Ancorichnus; J. Paleontol. 58(2) 511-528.

Frey R W and Pemberton S G 1987 The Psilonichnus ichnocoenose, and its relationship to adjacent marine and nonmarine ichnocoenoses along the Georgia coast; Bull. Can. Petrol. Geol. 35 333-357.

Genise J F and Bown T M 1994 New trace fossils of termites (Insecta: Isoptera) from the late Eocene-early Miocene of Egypt, and the reconstruction of ancient isopteran behavior; Ichnos 3 155-183.

Genise J F, Mángano M G, Buatois L A, Laza J and Verde M 2000 Insect trace fossil associations in paleosols: The Coprinisphaera ichnofacies; Palaios 15 49-64.

Gevers T W, Frakes L A, Edwards L N and Marzolf J E 1971 Trace fossils in the Lower Beacon sediments (Devonian), Darwin Mountains, southern Victoria Land, Antarctica; J. Paleontol. 45 81-94.

Gibert J M de and Saez A 2009 Paleohydrological significance of trace fossil distribution in Oligocene fluvial-fan-to-lacustrine systems of the Ebro Basin, Spain; Palaeogeogr. Palaeoclimatol. Palaeoecol. 272162 175 .

Gierlowski-Kordesch E 1991 Ichnology of an ephemeral lacustrine/alluvial plain system: Jurassic East Berlin Formation, Hartford Basin, USA; Ichnos 1 221-232.

Goldring R and Pollard J E 1995 A re-evaluation of Ophiomorpha burrows in the Wealden Group (Lower Cretaceous) of southern England; Cret. Res. 16 665-680.

Gouramanis C and Mcloughlin S 2016 Siluro-Devonian trace fossils from the Mereenie Sandstone, Kings Canyon, Watarrka National Park, Amadeus Basin, Northern Territory, Australia; Alcheringa 40 118-128. 
Gradzinski R and Uchman A 1994 Trace fossils from interdune deposits - an example from the Lower Triassic aeolian Tumlin Sandstone, central Poland; Palaeogeogr. Palaeoclimatol. Palaeoecol. 108 121-138.

Groves J 1916 On the name Lamprothamnus Braun; J. Bot. 54 336-337.

Hall J 1847 Palaeontology of New York: Volume I. Containing Descriptions of the Organic Remains of the Lower Division of the New York System (Equivalent of the Lower Silurian Rocks of Europe). C Van Benthuysen, Albany, $338 \mathrm{p}$.

Häntzschel W 1975 Trace fossils and problematica; In: Treatise on invertebrate paleontology Pt. W Miscellanea (ed.) Teichert C, Geological Society of America and University of Kansas Press, Boulder, Colourado, Lawrence, Kansas, pp. W1-W269.

Hasiotis S T 2004 Reconnaissance of Upper Jurassic Morrison Formation ichnofossils, Rocky Mountain Region, USA: Paleoenvironmental, stratigraphic and paleoclimatic significance of terrestrial and freshwater ichnocoenoses; Sedim. Geol. 167 177-268.

Hasiotis S T 2007 Continental ichnology: Fundamental processes and controls on trace fossil distribution; In: Trace fossils: Concepts, problems, prospects (ed.) Miller W III, Elsevier, Amsterdam, pp. 268-284.

Hasiotis S T 2008 Reply to the comments by Bromley et al. of the paper 'Reconnaissance of the Upper Jurassic Morrison Formation ichnofossils, Rocky Mountain Region, USA: Paleoenvironmental, stratigraphic, and paleoclimatic significance of terrestrial and freshwater ichnocoenoses' by Stephen T. Hasiotis; Sedim. Geol. 208 61-68.

Hartmann G 1964 Asiatische Ostracoden. Systematische und zoogeographische Untersuchungen; Internat. Revue der gesamten Hydrobiol. System. Beihefte. 31 155.

Heer O 1877 Flora fossilis Helvetiae. Die vorweltliche Flora der Schweiz; Verlag von Journal of Wurster and Company; Zürich, pp. 1-182.

Hembree D I and Hasiotis S T 2008 Miocene vertebrate and invertebrate burrows defining compound paleosols in the Pawnee Creek Formation, Colorado, U.S.A; Palaeogeogr. Palaeoclimatol. Palaeoecol. 270 349-365.

Hu B and Wu X T 1993 Ichnocoenosis of alluvial Jiaguan Formation (Upper Cretaceous), Emei, Sichuan, China; Act. Palaeontol. Sin. 32 478-489 (in Chinese with English abstract).

Hunt A P and Lucas S G 2007 Tetrapod ichnofacies: A new paradigm; Ichnos 14 59-68.

Johnson N M, Opdyke N D, Johnson G D, Lindsay E H and Tahirkheli R A K 1982 Magnetic polarity stratigraphy and ages of Siwalik Group rocks of the Potwar Plateau, Pakistan; Palaeogeogr. Palaeoclimatol. Palaeoecol. 37 17-42.

Karunakaran C and Ranga Rao A 1976 Status of exploration for hydrocarbons in the Himalayan region - Contributions to stratigraphy and structure; Geol. Soc. India. Misc. Publ. 41 1-66.

Keighley D G and Pickerill R K 1994 The ichnogenus Beaconites and its distinction from Ancorichnus and Taenidium; Palaeontology 37 305-337.

Keighley D G and Pickerill R K 1997 Systematic ichnology of the Mabou and Cumberland groups (Carboniferous) of western Cape Breton Island, eastern Canada, 1: burrows, pits, trails, and coprolites; Atlant. Geol. 33 181-215.

Kim J Y, Keighley D G, Pickerill R K, Hwang W and Kim K S 2005 Trace fossils from marginal lacustrine deposits of the Cretaceous Jinju Formation, southern coast of Korea; Palaeogeogr. Palaeoclimatol. Palaeoecol. 218 105124.

Kim J Y, Kim K S and Pickerill R K 2002 Cretaceous nonmarine trace fossils from the Hasandong and Jinju formations of the Namhae Area, Kyongsangnamdo, southeast Korea; Ichnos 9 41-60.

Krapovickas V, Ciccioli P L, Mángano M G, Marsicano C A and Limarino C O 2009 Paleobiology and paleoecology of an arid-semiarid Miocene South American ichnofauna in anastomosed fluvial deposits; Palaeogeogr. Palaeoclimatol. Palaeoecol. 284 129-152.

Kumaravel V, Sangode S J, Kumar R and Siddaiah N S 2005 Magnetic polarity stratigraphy of Plio-Pleistocene Pinjor Formation (type locality), Siwalik Group, NW Himalaya, India; Curr. Sci. 88(9) 1453-1461.

Kumar R and Tandon S K 1985 Sedimentology of Plio-Pleistocene late orogenic deposits associated with intraplate subduction: The Upper Siwalik subgroup of a part of Panjab Sub-Himalaya, India; Sedim. Geol. 105 $1-59$.

Lima J H D and Netto R G 2012 Trace fossils from the Permian Teresina Formation at Cerro Caveiras (S. Brazil); Rev. Bras. Paleontol. 15(1) 5-22.

Lucas S G 2016 Two new, substrate-controlled nonmarine ichnofacies; Ichnos 23(3-4) 248-261.

MacNaughton R B and Pickerill R K 1995 Invertebrate ichnology of the nonmarine Lepreau Formation (Triassic), southern New Brunswick, Eastern Canada; J. Paleontol. 69 160-171.

Mángano M G, Labandeira C C, Kvale E P and Buatois L A 2001 The insect trace fossil Tonganoxichnus from the Middle Pennsylvanian of Indiana: Paleobiologic and paleoenvironmental implications; Ichnos 8 165175 .

Mángano M G, Buatois L A, Maples C G and West R R 2002 Ichnology of a Pennsylvanian equatorial tidal flat; the Stull Shale Member at Waverly, eastern Kansas; Kansas Geol. Surv. Bull. 245 1-133.

Maples C G and Archer A 1989 The potential of Paleozoic nonmarine trace fossils for paleoecological interpretations; Palaeogeogr. Palaeoclimatol. Palaeoecol. 73 185-195.

Melchor R N, Bedatou E, Valais S D and Genise J F 2006 Lithofacies distribution of invertebrate and vertebrate trace-fossil assemblages in an Early Mesozoic ephemeral fluvio-lacustrine system from Argentina: Implications for the Scoyenia ichnofacies; Palaeogeogr. Palaeoclimatol. Palaeoecol. 239 253-285.

Mikuláš R, Lehotský T and Bábek O 2004 Trace fossils of the Moravice Formation from the southern Nízký Jeseník Mts. (Lower Carboniferous, Culm facies; Moravia, Czech Republic); Bull. Geosci. 79(2) 81-98.

Miller MP and Smail SE 1997 A semiquantative field method for evaluating bioturbation on bedding planes; Palaios 12 391-396.

Morrissey L B and Braddy S J 2004 Terrestrial trace fossils from the Lower Old Red Sandstone, southeast Wales; Geol. J. 39 315-336. 
Morrissey L B, Hillier R D and Marriott S B 2012 Late Silurian and Early Devonian terrestrialisation: Ichnological insights from the Lower Old Red Sandstone of the Anglo-Welsh Basin, U.K; Palaeogeogr. Palaeoclimatol. Palaeoecol. 337-338 194-215.

Nadon G C 1993 The association of anastomosed fluvial deposits and dinosaur tracks, eggs, and nests: Implications for the interpretation of floodplain environments and a possible survival strategy for ornithopods; Palaios 8 31-44.

Neto de Carvalho C and Baucon A 2016 Ichnology of alluvialfan related sequences: The example of Sarzedas Basin (Upper Miocene, UNESCO Naturtejo Geopark); Comun. Geol. 103(Especial I) 93-100.

Nicholson H A 1873 Contribution to the study of the errant annelids of the older Paleozoic rocks; Proc. Roy. Soc. London $21288-310$.

Opdyke N D, Lindsay E H, Johnson G D, Tahirkheli R A K and Mirza M A 1979 Magnetic polarity stratigraphy and vertebrate palaeontology of the Upper Siwalik subgroup of Northern Pakistan; Palaeogeogr. Palaeoclimatol. Palaeoecol. 27 1-34.

Osgood R G 1970 Trace fossils of the Cincinnati area; Palaeontolog. Amer. 41 282-444.

Patnaik R 1997 New murids and gerbillids (rodentia, mammalia) from Pliocene Siwalik sediments of India; Palaeovertebrata 26(1-4) 129-165.

Patnaik R 2003 Reconstruction of Upper Siwalik palaeoecology and palaeoclimatology using microfossil palaeocommunities; Palaeogeogr. Palaeoclimatol. Palaeoecol. $197133-150$.

Pemberton S G and Frey R W 1982 Trace fossil nomenclature and the Planolites-Palaeophycus dilemma; J. Paleontol. 56 843-871.

Pickerill R K 1992 Carboniferous nonmarine invertebrate ichnocoenoses from southern New Brunswick, eastern Canada; Ichnos 2 21-35.

Pilgrim G E 1910 Preliminary note on a revised classification of the Tertiary freshwater deposits in India; Rec. Geol. Surv. India. 40 185-205.

Pilgrim G E 1913 The correlation of the Siwaliks with the mammalian horizons of Europe; Rec. Geol. Surv. India 43 264-325.

Pollard J E, Steel R J and Undersrud E 1982 Facies sequences and trace fossils in lacustrine/fan delta deposits, Hornelen Basin (M. Devonian), western Norway; Sedim. Geol. 32 63-87.

Pollard J E and Walker E F 1984 Reassessment of sediments and trace fossils from Old Red Sandstone (Lower Devonian) of Dunure, Scotland, described by John Smith (1909); Geobios 17 567-576.

Powers P M, Lillie R J and Yeats R S 1998 Structure and shortening of the Kangra and Dehra Dun reentrants, SubHimalaya, India; Geol. Soc. Am. Bull. 110 1010-1027.

Raiverman V, Kunte S V and Mukherjea A 1983 Basin geometry, Cenozoic sedimentation and hydrocarbon prospects in northwestern Himalaya and Indo-Gangetic plains; Petrol. Asia J. 6 67-92.

Ranga Rao A, Nanda A C, Sharma U N and Bhalla M S 1995 Magnetic polarity stratigraphy of the Pinjore Formation (Upper Siwaliks) near Pinjore, Haryana; Curr. Sci. 68 1231-1236.
Retallack G J 2001 Scoyenia burrows from Ordovician palaeosols of the Juntia Formation in Pennsylvania; Palaeontology 44(2) 209-235, https://doi.org/10.1111/ 1475-4983-00177.

Ridgway J M 1974 A problematical trace fossil from the New Red Sandstone of south Devon; Proc. Geol. Assoc. 85 $511-517$.

Sars G O 1890 Oversigt af Norges Crustaceer med forelebige Bemærkninger over de nye eller mindre bekjendte Arter; Forhandlinger $i$ Christiania VidenskabsSelskabet (Oslo) 1890(1) 1-80.

Sars G O 1903 Fresh-water Entomostraca from China and Sumatra; Archiv for Mathematik og Naturvidenskab. 25(8) 1-44.

Savrda C E, Blanton-Hooks A D, Collier J W, Drake R A, Graves R L, Hall A G, Nelson A I, Slone J C, Williams D D and Wood H A 2000 Taenidium and associated ichnofossils in fluvial deposits, Cretaceous Tuscaloosa Formation, eastern Alabama, southeastern U.S.A; Ichnos 7 223242.

Schlirf M, Uchman A, and Kümmel M 2001 Upper Triassic (Keuper) non-marine trace fossils from the Haßberge area (Franconia, south-eastern Germany); Paläontol. Zeitsch. 75 71-96.

Scott J J, Renaut R W, Buatois L A and Owen R B 2009 Biogenic structures in exhumed surfaces around saline lakes: An example from Lake Bogoria, Kenya Rift Valley; Palaeogeogr. Palaeoclimatol. Palaeoecol. 272 176-198, https://doi.org/10.1016/j.palaeo.2008.12.002.

Seilacher A 1963 Lebensspuren und Salinitatsfazies; Fortsch. Geol. Rheinl. und Westf. 10 81-94.

Seilacher A 1967 Bathymetry of trace fossils; Mar. Geol. 5 413-428.

Smith R M H 1993 Sedimentology and ichnology of floodplain paleosurfaces in the Beaufort Group (Late Permian), Karoo Sequence, South Africa; Palaios 8 339-357.

Smith R M H and Mason T R 1998 Sedimentary environments and trace fossils of Tertiary oasis deposits in the Central Namib Desert, Namibia; Palaios 13 547-559.

Soulié-Märsche I 1989 Etude comparée de gyrogonites de Charophytes actuelles et fossiles et phylogénie des genres actuels, Thése-és-Sci. Université des Sciences et Techniques du Languedoc, Montpellier, Thêse d'Etat, $237 \mathrm{p}$.

Tandon S K 1991 The Himalayan Foreland: Focus on Siwalik Basin; In: Sedimentary Basins of India: Tectonic Context (eds) Tandon S K, Pant C C and Casshyap S M, Gyanodaya Prakashan, Nainital, India, pp. 177-201.

Tandon S K and Kumar R 1984 Discovery of tuffaceous mudstones in the Pinjore Formation of Panjab Sub-Himalaya, India; Curr. Sci. 53 982-984.

Tandon S K and Naug B 1984 Facies-trace fossil relationships in a Plio-Pleistocene fluvial sequence, the Upper Siwalik subgroup, Punjab sub-Himalaya, India; Palaeogeogr. Palaeoclimatol. Palaeoecol. $47277-$ 299.

Thuillier J L 1799 La Flore des Environs de Paris, ou distribution methodique des plantes qui y croissent naturellement; Chez 1'auteur, Paris, France, 595p.

Uchman A 1999 Ichnology of the Rhenodanubian Flysch (Lower Cretaceous-Eocene) in Austria and Germany; Beringeria 25 65-171. 
Uchman A, Pika-Biolzi P and Hochuli P A 2004 Oligocene trace fossils from temporary fluvial plain ponds: an example from the Freshwater Molasse of Switzerland; Eclogae Geol. Helvet. 97 133-148.

Wang M, Qi Y A, Li D, Dai M Y and Chang Y G 2014 Ichnofabrics and their environmental interpretation from the fluvial deposits of the Middle Triassic Youfangzhuang Formation in Western Henan, Central China; J. Earth Sci. 25(4) 648661.

Corresponding editor: Pratul K Saraswati
Wang C Z, Wang J, Hu B and Lu X H 2016 Trace fossils and sedimentary environments of the Upper Cretaceous in the Xixia Basin, southwestern Henan Province, China; Geodin. Act. 28(1-2) 53-70.

White C D 1929 Flora of the Hermit Shale, Grand Canyon, Arizona; Carnegie Inst. Washington Pub. 405 1-221.

Zhang G C, Guo W X and Zeng Y F 2004 Ichnofabrics from the Upper Cretaceous fluvial and lacustrine deposits in Xixia Basin, Henan; J. Palaeogeogr. 6 434-441 (in Chinese with English abstract). 